\title{
The Motivation and Strategy on Higher Vocational Education to Serve County Area Development on the New Period
}

\author{
Q.F. YAO \\ Zhejiang Business Technology Institute, Ningbo, China
}

\begin{abstract}
The county new four modernization construction has been forwarded as a significant thesis for new development of higher vocational education, it also provides a good chance for higher vocational education to serve regional economy and social development. The higher vocational education ought to play an important role in high skill talents, applied technology research and development, high quality social service and culture leading with regional characteristics. It should become main force in the construction of new four modernization in the county area.
\end{abstract}

KEYWORD: Higher vocational education; collaboration between college and county; coordination and innovation; social services

\section{INTRODUCTION}

The county area new four modernization for industrialization, informationization, urbanization and agricultural modernization based on new four modernization construction strategy is a development mode transformation of the national economy from regional area to county area [1]. The new thesis of new development for higher vocational education will have to lead to a great change in higher vocational education sector. It will also bring an important historic chance for higher vocational education by achieving its development goals during the important strategic opportunity period and the key historic joint moment.

\section{REALISTIC CHOICE STRATEGY OF CONSTRUCT HIGHER VOCATIONAL EDUCATION FOR SERVICE FOR THE NEW FOUR MODERNIZATION}

The higher vocational education with both dual attributes of "professional" and "higher" has come out with scale expansion and opportunities for growth as the core of historical period has entered a new stage in order to improve the content and quality and making brand and core characteristics [2]. The critical issue is how higher vocational colleges to seek the characteristics of road for sustainable development? Its essence is that higher vocational colleges take "what" to compete with regional universities especially applied undergraduate colleges. In other way, how higher vocational colleges can go its own way with its advantage and go dislocation development road with undergraduate colleges (Applied).

In fact, higher vocational education takes employment as the orientation, to make service as an objective, to make the way of production-studyresearch combination as its educational policy. It inherently stipulates "the dislocation development road", that is to make cooperation in running schools, to make cooperative education, to make cooperative employment and takes cooperation and development as the main line. The" new four modernizations "construction under the background of the times, higher vocational colleges must transform idea, make full use of its own advantage, make full cooperation with county in the high skill talents training and other aspects, go down the road of development and make implementation with regional universities especially dislocation development of Applied Undergraduate colleges.

Therefore, the higher vocational colleges must make cooperation with local area by cooperation between county and colleges, cooperation between district and colleges and even cooperation between township and colleges to deepen higher vocational education policy, to improve county service ability and to increase regional service capability. The process of improving regional and county service competency is also the process of showing 
competition strength to its competitor. It is the process to improve competitiveness of its own.

\section{STRONG SUPPORT}

\subsection{Higher vocational education provides a strong support for the industrialization of county}

As a representative of the manufacturing industry, it is the pillar industry in the county. It plays a decisive role in the county economy as essence of the county. It has special functions to expand the county, to improve quality of the county and promote the county to a upper level [3]. Moreover, the county industry is the basis of made in China. However, the present situation of the manufacturing lays in middle and low technology production. The transformation and upgrading of the county manufacturing industry is more difficult to compare with those urban manufacturing. That is to say it is not an easy job to transform county manufacturing industry from a low technology level, low added value to high technology and high added value regarding its scale growth, expansion of industry chain, updating industry level or the industrial agglomeration improvement, the industrial innovation capability and management ability.

However, in the final analysis, made in county or made in China needs strong support of talent, which also needs support of a large number of high skill manufacturing talents for industry development services from higher vocational education colleges. It also needs intellectual support and technical support of higher vocational colleges to achieve leap forward from medium and low-end products to highend products for manufacturing industry.

\subsection{Higher vocational education provides a strong support for the informatization construction of county}

The industry development issues behind information construction of county are a development issue of county service industry. The service industry is a trend of county industry. Furthermore, the issue of informatization construction and county service industry development is an integration development issue of advanced manufacturing industry and modern service industry in the county. So the information construction requires the highest degree of technical as well as the highest degree of industrialization in the new four modernizations construction.

At present, China is facing a daunting task of industrial transformation and economic development mode transformation and upgrading. To break major bottleneck of transformation and upgrading of industrial structure, it is crucial to solve interaction problem of "double engine" (i.e., advanced manufacturing industry as "wings" and modern service industry as "intelligent head"). As to the development of service industry, it is urgent issue how manufacturing industry service or service oriented manufacturing adapt to tendency of rapid development production service to increase integration of service industry and manufacturing industry in order to accelerate the construction of informationization. Higher vocational colleges should be based on reality and look to the future and should develop high skill talents suitable for development of productive service.

\subsection{Higher vocational education provides a strong support for county urbanization}

The core issue of new urbanization is people urbanization. It is a transfer issue of rural surplus labor and migrant workers citizenization in nature. There are two basic paths to transfer rural surplus labor force [4]. The first one is to transfer surplus rural labor to cities, but the biggest problem is how to solve problem of peasant workers' citizenization. The special remind has to be noted for no misread the rate of urbanization. We have to see another side of Chinese urbanization with Chinese feature. The real rate is only $36 \%$. This number deducts those who are not really entering the city's population. The number of no entering city's population reached 0.26 billion people. It mainly refers to the "urbanization" of migrant workers [5]. It is a urgent issue is to promote public service construction equalization of the whole society (urban and rural) for promotion of peasant workers' citizenization, The higher vocational education which is good at professional technology, professional spirit, professional ethics education plays an irreplaceable role on the equalization of public service construction. In this process, higher vocational colleges must not only train and improve migrant workers ability for urban jobs and business skills but also help and them to integrate into urban society and become new citizen.

The other path is to help rural surplus labor force become into urbanization in the local area. That indicates that county town can also be become into an important gathering area for rural surplus labor force. The path can reduce and share the pressure of peasant workers to become citizenization. Therefore, it is an important basis to build Chinese characteristic urbanization with county (city) town as center of the county development. Introduction of higher education especially higher vocational education which fit better with county development with both "high" and "professional" can help and promote science and technology progress to leading industry of county, design of strategic planning for overall development, guidance and comprehensive construction well-off society matched County culture. Higher vocational colleges serve county 
development and it consumes the local labor force and provides solid soil for them". Of course, higher vocational colleges can also provide service to consume local labor force directly by implementation of special, targeted and quality professional skills and quality improvement project.

\subsection{Higher vocational education provides strong support for construction of agricultural modernization}

Agriculture is the foundation industry in the county. So agricultural modernization is connected with county overall development. In this regard, 2014 No.1 document of the central government required to promote agricultural science and technology innovation and perfect integration mechanism of urban and rural development and particularly stressed to make full use of high education in agricultural research and promotion. It puts forward a new and high requirement for vocational Education especially higher vocational education, which is based in agricultural industry. Higher vocational colleges are their unshirkable responsibility to make service for agricultural industry with obvious advantages comparing with ordinary education. Moreover, vocational and technical education, which is good at cultivating high skilled talents, has more advantages than secondary vocational education in county. Besides, higher vocational education colleges have more advantages with better characteristics and better enthusiastic in full and deep service to county agricultural industry comparing with ordinary universities.

\section{MAIN FORCE ROLE IN CONSTRUCTION OF NEW FOUR MODERNIZATIONS}

Regarding new four modernizations construction and innovation demand, higher vocational education should extend their service actively to the county area, run schools in deep county hinterland.

\subsection{Vigorously promote the county school collaborative innovation}

The 2011 plan as the core of cooperative innovation provides great development opportunities for higher vocational colleges. As it is the first national strategy to put all universities in the same starting line on the development of higher education (it is the third national strategy after the "project 211" and "985 Project").

Therefore, higher vocational colleges should make full use of its faculty, technology, information and other advantages. It can achieve cooperation through county school collaboration and reach innovation synergy through county school collaborative innovation and then achieve the "combination of production, learning and research" collaborative innovation. Thus it can form a longterm mechanism of collaborative innovation by the government guidance, vocational colleges (leveraging leading role of undergraduate colleges and universities' power) and enterprises leading, the active participation of science and technology organization and social forces, the smooth use by users (Transform and application of scientific and technological achievements convenience).

\subsection{Strongly propel management innovation of school system in the county area}

It is an urgent problem how higher vocational colleges make effective management to run county school in promoting collaborative innovation. Thus, problems in the construction of school running mode of county in vocational colleges are sure to produce school running mechanism problem which also produces a school pattern construction issues of higher vocational education headquarters base in the county with the specific context. Therefore, the school pattern of headquarters base in higher vocational education becomes a typical issue in management innovation of constructing school pattern.

\subsection{Take innovation measures as functional advantage in higher vocational education}

The measures in county school collaborative innovation and school pattern and management innovation to run school in county should specifically implement on the quality of talent, scientific research, social services and cultural heritage and the leading function of the school running results with pertinence and feature.

First, higher vocational colleges have to optimize its personnel training quality. It is not only to optimize program structure, target orientation and teaching materials of high skilled talents based on county actual needs, but also have to strengthen education and guidance to students on employment choice in order to have more vocational graduates to work in the county. Secondly, higher vocational colleges have to carry out research and technology application work. Higher vocational colleges should focus on technology and research difficulties in new four modernizations construction and combination area between their faculty and advanced equipment advantage to start applied technology and research work and to conduct county school cooperation and science technology innovation efficiently. Third, it is important to put correct relationship between talents cultivation and skills training work. The higher vocational colleges should change current situation on paying more attention to degree education and 
looking down on skills training. The colleges should expand county oriented skills training (identification) scale and gradually go with two legs by talents cultivation and skills training and help upgrade technical skills of County and raise technical level. Finally, higher vocational colleges should actively participate and lead special county cultural activities. Higher vocational colleges should assist county area to sort out and inherit traditional culture and play a leading role in the county cultural prosperity and innovation in order to promote county cultural level to overall raise.

\section{CONCLUSION}

County school collaborative innovation activities by vocational education relates to the county level government and colleges as the leading multi-body or interesting aspects. It is also affected by vocational colleges where regional economic development level and science and technology development level and its resources. Therefore, we must establish a long-term mechanism, including investment mechanism, operation mechanism, evaluation mechanism and assurance mechanism. Among them, the operation mechanism forms the core content of long-term mechanism. Regarding collaborative innovation evaluation of Higher Vocational Education, the social evaluation is one of the important aspect in addition to the participation main body self diagnosis.

\section{ACKNOWLEDGEMENTS}

This paper is the research finding of Ningbo's soft science program Study of the implement strategy and operation mechanism in Collaborative Innovation of the County-College Cooperation in Ningbo (program No. 2013A10082) and Ningbo's Philosophy and Social Science Planning Project Study of the Collaborative Innovation mechanism of the CountyCollege Cooperation in Ningbo (program No. G13GJ01).

\section{REFERENCES}

[1] Liu, B.L. 2012. Industrial first, urban second, "Industrial new city" describes future urbanization. Chinese economic review.

[2] Shi, Z.Y. 2012. Quality Improvement is the core mission of education reform. Chinese education newspaper.

[3] Cai, Z.W. 2013. An Empirical Research of the Promotion towards Manufacture Industrial Level: Based on the Development of Ningbo's Producer services. Zhejiang University Press, Hangzhou.

[4] Wang, W. 2012. China's Urbanization Facing the Turning Point. People's Daily.

[5] 2012. More Concern Should Be Made on the Quality of Urbanization. China Business News. China Business News Press. 